\title{
Cloning and sequencing of sakP encoding sakacin $P$, the bacteriocin produced by Lactobacillus sake LTH 673
}

\author{
Petra S. Tichaczek, Rudi F. Vogel† and Walter P. Hammes \\ Author for correspondence: Rudi F. Vogel. Tel: +49816171 3284. Fax: +498161714418.
}

Institut für

Lebensmitteltechnologie, Universităt Hohenheim, 70599 Stuttgart, Germany

\begin{abstract}
Sakacin $P$ is a heat-stable, unmodified peptide bacteriocin produced by Lactobacillus sake LTH 673. The strain was isolated from fermented dry sausages and is well adapted to this habitat. The bacteriocin inhibits the growth of the opportunistic food pathogens Enterococcus faecalis and Listeria monocytogenes and therefore, it may improve the hygienic status of fermented food, i.e. meat products. Oligonucleotide probes were designed from the $\mathbf{N}$-terminal amino acid sequence of sakacin $P$ and used to identify sakP, the structural gene of sakacin $P$, on the chromosome of $L$. sake LTH 673 . SakP was cloned into Escherichia coli NM554 and the nucleotide sequence of the gene and its adjacent regions were determined. Sakacin P appears to be synthesized as a prepeptide of 61 amino acids which is proteolytically processed to the mature bacteriocin consisting of $\mathbf{4 3}$ amino acids. Sequencing of the cloned fragment also revealed the presence of two other open reading frames orfX and orfY, which are located upstream and downstream of sakP, respectively, putatively encoding proteins of 52 and 98 amino acids, respectively. The functions of both ORFs remain unknown. Primer extension analysis revealed a promoter upstream of sakP. Two transcripts of approximately 0.35 and $1.0 \mathrm{~kb}$ were detected by Northern hybridization encoding either only sakP, or both sakP and orfY, respectively.
\end{abstract}

Keywords: Lactobacillus sake, bacteriocin, sakacin P, sakP, food hygiene

\section{INTRODUCTION}

Antimicrobial activities of lactic acid bacteria (LAB) have been investigated since 1951 (Wheater et al., 1951; Vincent et al., 1959; Daeschel, 1989; Hammes et al., 1990). Whereas unspecific, broad-spectrum inhibition is generally attributed to organic acid production and/or to hydrogen peroxide, a narrow inhibitory spectrum, mainly including closely related species, can be linked to the synthesis and the secretion of bacteriocins. These substances are antimicrobial peptides or proteins, whose bactericidal or bacteriostatic activity usually is directed against a few bacterial species (Tagg et al., 1976; Klaenhammer, 1988). However, some bacteriocins of LAB also inhibit pathogens and spoilage organisms found in foods, and thus, they may be of interest in process control and food

\footnotetext{
†Present address: Lehrstuhl für Technische Mikrobiologie, Technische Universităt München, 85350 Freising, Germany.
}

The GenBank accession number for the sequence reported in this paper is $X 75081$. preservation. On the basis of the protein structure of LAB bacteriocins, several groups can be distinguished (Tichaczek et al., 1993). The unmodified peptide bacteriocins share some similarities, i.e. they have a N-terminal sequence proteolytically cleaved off before or during secretion (Hastings et al., 1991; Holo et al., 1991). Comparing the amino acid sequences of some mature peptide bacteriocins revealed the common sequence $Y-G-$ $\mathrm{N}-\mathrm{G}-\mathrm{V}-\mathrm{X}-\mathrm{C}$ in their N-terminal region, indicating that this consensus sequence may be of importance for this group of bacteriocins (Lozano et al., 1992).

A number of bacteriocin genes have recently been cloned and sequenced including lactococcins (van Belkum et al., 1989, 1991; Holo et al., 1991), helveticin J (Joerger \& Klaenhammer, 1990), lactacin F (Muriana \& Klaenhammer, 1991) and leucocin A-UAL 187 (Hastings $e t$ al., 1991). Some bacteriocins have been shown to be either plasmid encoded (Daeschel \& Klaenhammer, 1985; Buchman et al., 1988; Mørdtvedt \& Nes, 1990; Muriana \& Klaenhammer, 1991; Tichaczek et al., 1993) or located on the chromosome (Barefoot \& Klaenhammer, 1983; 
Joerger \& Klaenhammer, 1986; Grinstead \& Barefoot, 1992). A strain can produce more than one bacteriocin as shown for Lactobacillus plantarum LPCO10 (Jiménez-Díaz et al., 1993) and Lactococcus lactis subsp. cremoris 9B4. From the latter strain the genes encoding three different lactococcins and their respective immunity proteins have been cloned and sequenced (van Belkum et al., 1991, 1992). For the production of active lactococcin, two additional genes $(\operatorname{lcn} C$ and $\operatorname{lcn} D)$ are required, which are implicated in secretion (Stoddard et al., 1992). The genes involved in the production of pediocin PA-1 are organized in an operon which includes the structural gene and additional ORFs which are required for bacteriocin biosynthesis (Marugg et al., 1992).

Cloning and sequencing of bacteriocin genes and their adjacent regions allow insight into their biosynthesis, transport and regulation. This knowledge can be used to develop new protective starter organisms with the potential to improve both the hygienic status of food and their competitiveness in food fermentations (Schillinger $e t$ al., 1991; Foegeding et al., 1992; Vogel et al., 1993). Due to the inhibitory spectrum of their bacteriocins, L. curvatus LTH 1174 and L. sake LTH 673 producing curvacin A and sakacin P, respectively (Tichaczek et al., 1992), are likely candidates for application in meat fermentation. The gene encoding curvacin $\mathrm{A}$ has been cloned and sequenced recently ('Tichaczek et al., 1993).

The present work describes the cloning and nucleotide sequencing of the DNA region containing sakP, the gene encoding the peptide bacteriocin sakacin P. This heatstable unmodified peptide bacteriocin is produced by Lactobacillus sake LTH 673 and inhibits strains of some Lactobacillus species as well as Listeria monocytogenes, Enterococcus faecalis and Carnobacterium sp. (Tichaczek et al., 1992).

\section{METHODS}

Bacterial strains, plasmids and media. Lactobacillus sake LTH 673 was isolated from fermented sausage. Escherichia coli HB102 harbouring pRB473 was kindly provided by R. Brückner, Tübingen, Germany. E. coli NM554 and the plasmid vector pBluescript SK + (Stratagene) were used for cloning experiments. L. sake LTH 673 was grown in MRS medium (de Man it al., 1960) at $30^{\circ} \mathrm{C}$. E. coli strains were propagated at $37^{\circ} \mathrm{C}$ in SOB broth with shaking (180 r.p.m.) or on SOB agar plates (Hanahan, 1983). Selective media contained ampicillin at a final concentration of $100 \mu \mathrm{g} \mathrm{ml}^{-1}$ [SOB(amp)]. Bacteriocin production by L. sake LTH 673 was determined as described previously (Tichaczek et al., 1992).

Construction and amplification of the genomic library. DNA of L. sake LTH 673 and E. coli was isolated as described before (Tichaczek et al., 1993). Chromosomal DNA of L. sake LTH 673 was cleaved with $B c /$ I. DNA fragments of approximately $6 \mathrm{~kb}$ were isolated from preparative $0.8 \%$ agarose gels by the method of Dretzen et al. (1981). The fragments were ligated into the BamHI-digested pRB473 vector with T4 DNA ligase (Boehringer). The ligation mixture was used to transform competent E. coli NM554 cells by the method of Hanahan (1983). The transformants were washed off the agar plates and collected by centrifugation. The cells were resuspended in a total volume of $1 \mathrm{ml}$ of $\mathrm{SOB}(\mathrm{amp})$ medium and mixed with an equal volume of sterile $60 \%(\mathrm{v} / \mathrm{v})$ glycerol and stored at $-85^{\circ} \mathrm{C}$.

Detection and cloning of sakP. For the detection of $s a k P$ in Southern hybridizations, DNA of L. sake LTH 673 was digested with various restriction enzymes and the fragments were separated in $0.8 \%$ agarose gels according to their size. HindIII fragments of bacteriophage $\lambda$ DNA (Boehringer) were used as molecular mass markers.

A sakacin P-specific probe for DNA hybridizations was deduced from the sequence of the amino acids 11-19 of purified sakacin P which was KHSCTVDWG (Tichaczek et al., 1992). The degeneration of this 26-mer oligonucleotide was 16-fold. The sequence was $5^{\prime} \mathrm{CCC} \mathrm{CAI} \mathrm{TCI}(\mathrm{C}) \mathrm{ACI}(\mathrm{C}) \mathrm{GTI} \mathrm{CAI}(\mathrm{C})$ G(C)II TGT TT $3^{\prime}$. The probe was end-labelled with $\left[\gamma^{32} \mathrm{P}\right]-$ ATP (Amersham) by using a $5^{\prime}$ terminus labelling system (Pharmacia). Prehybridization and hybridization with the probe was performed essentially as described by Sambrook et al. (1989) with modifications as described by Tichaczek et al. (1993).

Southern hybridizations of the fractionated DNA and detection of clones containing the bacteriocin gene were performed as described before (Tichaczek et al., 1993). Positive clones and subclones were cultured overnight in $10 \mathrm{ml} \mathrm{SOB}(\mathrm{amp})$ broth. Plasmids were isolated from the cultures, digested with HindIII/ EcoRI and inserts were analysed by Southern hybridization. Plasmid DNA of positive clones was isolated and cleaved with NruI/PvuII. For the construction of subclones, a $1.0 \mathrm{~kb}$ NruI/PvuII fragment was ligated into the EcoRV-digested pBluescript SK + vector and the ligation mixture was used to transform competent $E$. coli NM554 cells.

DNA sequencing and analysis. Double-stranded DNA sequencing and sequence analysis was performed as described previously (Tichaczek et al., 1993). The molecular mass of the peptides was calculated with the PRosis software (Pharmacia).

Analyses of the mRNA. mRNA was isolated from lactobacilli and $E$. coli by the method of Obst (1993). The site for transcription initiation was determined by primer extension analysis with reverse transcriptase (BRL). Two oligonucleotide primers were used which were complementary to the $5^{\prime}$ region of the mRNA (sakpr1, 5' ACCGTTACCATAATATT 3'; and sakpr2, 5' AAACTTTTCCATTAGAA 3'). For Northern hybridizations ${ }^{32} \mathrm{P}$ end-labelled sakpr1 was used as probe. Primer extension and Northern hybridization analysis were performed as described by Sambrook et al. (1989).

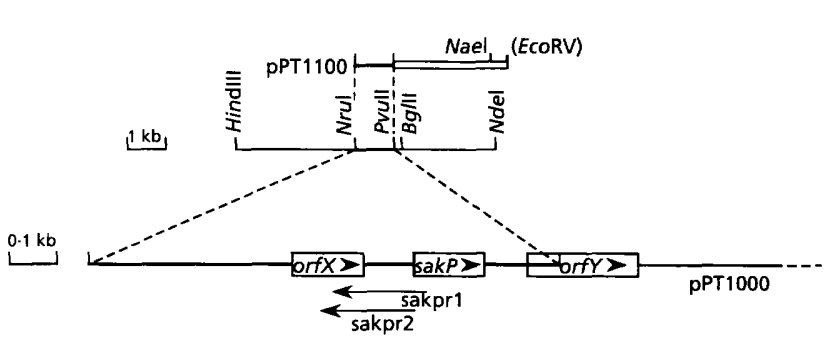

Fig. 1. Restriction map of the DNA fragment containing sakP and the location of the ORFs. The ORFs are indicated by boxes, with arrowheads showing the direction of transcription. sakpr 1 and sakpr2 were used for primer extension (compare Fig. 3). The arrows show the length and direction of the sequence runs obtained using these primers. Vector DNA is indicated by double lining. 
1 ACCATTAAAGGAAGTTGTITATTTATATACTGAAAAAGAAAATTCCGGGTCATATTAA

rbs

59 TITGTTAGCCGTTACCAGAAAGGTIACTTICCAGGAAATTTAAATGCGCT orfX>

118 ATATCCA ATG CTC TIT CGG TGT GAT AAA AGT TAC TTA GTT AAC CTA 163

\begin{tabular}{r|rccccccccccc|r}
164 & TCT AAT ATT GCC & AAT TAT & GAC & AGT & AAA & ACA & CGG & AGT & TTA & AAA & TIT & 13 \\
& 208
\end{tabular}

$\begin{array}{llllllllllllllll}\text { S } & N & I & A & N & Y & D & S & K & T & R & S & L & K & F & 28\end{array}$

209 GTA GAT GGC AGT GAG GCA AAA GTC TCG TTC CGG AAA TCA CGG GAA 253

$\begin{array}{llllllllllllllll}V & D & D & G & S & E & A & K & V & S & F & R & K & S & R & E\end{array}$

254 CTA GTG GCC AAA TTA AAA CAA ATG ATG TAG CGCATATTAACGTTTAA 300 $\begin{array}{lllllllllllllll}L & V & A & K & L & K & Q & M & M & * & & \end{array}$

301 CCGATAAAGTTGAACGTTAATATTTTT $\frac{-35}{-10}$

- 14 rbs

360 GTCTT噮AAGGTATTTAGCTGGCTGGCGTAAAGTATGCTITATAAAATAATATAT 418

419 SITATGATTTA ATG GAA AAG TTT ATT GAA TTA TCT TTA AAA GAA GTA 465

$\begin{array}{llllllllllllll} & M & E & K & F & I & E & L & S & L & K & E & V & 12\end{array}$

466 ACA GCA ATT ACA GGT GGA 4 \%

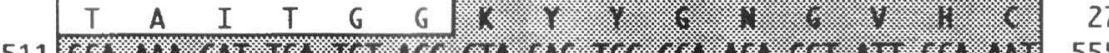

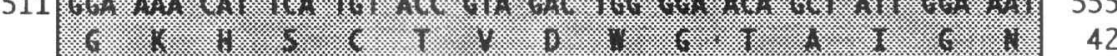

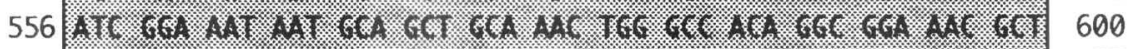

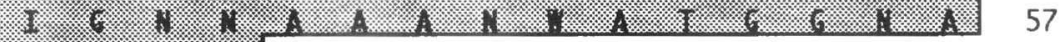

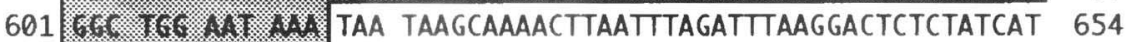
(C. * rbs * orfY $>61$

655 TTGATGGGGATTITTAGCTIATAGTAACAGAATAAAATAA 711

$\begin{array}{lll}712 & \text { AAA ATA TTG AAG TGG TAT TCA GGT GGT AAG GAT CGC GGA GAA CGG } & 1 \\ 756\end{array}$

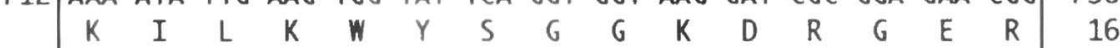

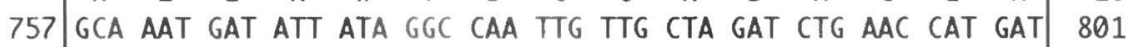

$\begin{array}{llllllllllllllll}\text { A } & N & D & I & I & G & Q & \text { L } & \text { L } & \text { L } & \text { D } & \text { L } & \text { N } & H & \text { D } & 31\end{array}$

802 CCA AAA AAT GAA CAT TTA GAA GCA ATA TTA ATA AAT TAT CAG AAT 846

$\begin{array}{lllllllllllllllll}P & K & N & E & H & L & E & A & I & L & I & N & Y & Q & N & 46\end{array}$

847 GAA ATT AAA AGG AAA GAA AGT TCG GTG CCA TTT ATT TTG AGT CGG 891

$\begin{array}{lllllllllllllllll}E & I & K & R & K & E & S & S & V & P & F & I & L & S & R & 61\end{array}$

892 ATG AAT ATA TCA ATA GCC AAT ACA ATC AGA AGA GAT AGG CTC ATT 936

$\begin{array}{llllllllllllllll}M & N & I & S & I & A & N & T & I & R & R & D & R & L & I & 76\end{array}$

937 TTA ACC GAT ITT CAA GAA GAT AAA TTG AAA TTG TTA ACT GCG TTG 981

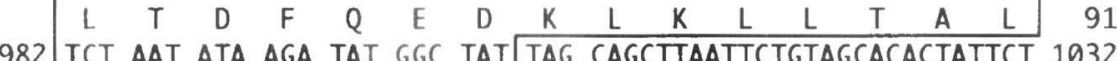

982 TCT AAT ATA AGA TAT GGC TAT TAG CAGCTTAATTCTGTAGCACACTATTCT 1032

1033 AAGAATACGCTAGAACTGTTATATGGAATITCAATATTAATTTGGTTGATAGTGAACT 1091 1092 TGATGAGATATTCATTATTATAATGTGTCATATAGTACGATTCGTTATTGCTGGTTATG 1150

1151 AATACATTGTAATGAAAAGATTAACGTITAATCTATACAATTATACGTTAGTCTITTIA 1209

1210 TITIATAagGaATAgCCATAATATAACAgCTTAGATtTTAAATGCAGCATtAaCGTTAA 1268

1269 TTITGATAAACGTAACGTTAATGGATAATCATCCTGTTTACAAATAGTGTATGACATAA 1327

1328 TTAAGTAATTAACTTACGGAGGCTCTT 1354

Fig. 2. Nucleotide sequence of sakP and its adjacent regions. The boxed areas indicate sakP, orfX and orf $Y$. The shaded box covers the mature sakacin $P$. The sequences responsible for transcription initiation and the putative ribosome binding sites are boxed and marked $1,-10,-35$ and rbs, respectively. The stop codons are marked with asterisks. Putative terminator sites are indicated by arrows. The $\Delta \mathrm{G}^{0}$ values of the terminator structures observed downstream of orf $X$, sakP and orfY were $-21 \cdot 1,-18 \cdot 1$ and $-18 \cdot 6 \mathrm{kcal} \mathrm{mol}^{-1}$, respectively. 


\section{RESULTS}

\section{Detection of sakP}

The structural gene encoding sakacin $\mathrm{P}(s a k P)$ was identified by Southern hybridization using a 26-mer oligonucleotide probe based on the amino acid sequence of sakacin P as determined by Tichaczek et al. (1992). No plasmids were detected in L. sake LTH 673 suggesting the chromosomal location of the hybridizing sequence. In Southern hybridizations with total DNA, a diffuse signal was obtained at the position of the chromosomal DNA in the gel. One strong signal was detected when total DNA of L. sake LTH 673 was subjected to single and double restriction enzyme digestions and analysed by Southern hybridization. The sakP gene was identified on a $5.8 \mathrm{~kb} \mathrm{BclI}$ fragment and a $1.0 \mathrm{~kb}$ NruI/PvuII fragment, respectively.

\section{Cloning and subcloning of sakP}

$\mathrm{Bcl}$ l-generated fragments of approximately $6 \mathrm{~kb}$ were ligated into plasmid pRB473 and cloned in E. coli NM554. Positive clones were detected by colony hybridization with the 26-mer oligonucleotide probe. Plasmid DNA was isolated from the hybridizing clones, digested with HindIII/EcoRI, and shown to contain a $5.8 \mathrm{~kb}$ insert of Lactobacillus DNA reacting with the probe. One of the plasmids harbouring the $5.8 \mathrm{~kb} \mathrm{BclI}$ DNA insert was designated pPT1000. The hybridizing $1.0 \mathrm{~kb} N r u \mathrm{I} / \mathrm{PvuII}$ fragment of pPT1000 was subcloned into the EcoRV site of pBluescript SK $+E$. coli NM554, resulting in pPT1100.

\section{Sequencing of the cloned fragments}

Sequencing of the $1.0 \mathrm{~kb}$ insert of pPT1100 and parts of the insert of pPT1000 revealed the presence of three ORFs that could encode polypeptides of 52, 98 and 61 amino acids referred to as orf $X$, orf $Y$ and $\operatorname{orf} Z$, respectively. The restriction map of the cloned fragment and the location of the ORFs are depicted in Fig. 1. Translation of orf $Z$ resulted in a sequence, part of which was identical to the amino acid sequence determined by Edman degradation of purified sakacin P (Tichaczek et al., 1992). Thus, $\operatorname{orf} Z$ is the structural gene encoding sakacin $P$ and will subsequently be referred to as sakP. The nucleotide sequence of sakP and its adjacent regions is shown in Fig. 2. The sakP primary product has a deduced $M_{\mathrm{r}}$ of 6380 , and the $M_{\mathrm{r}}$ values of the peptides putatively encoded by orf $X$ and orf $Y$ were calculated to be 6000 and 11500 , respectively.

\section{Analyses of the mRNA}

The site for transcription initiation was determined by primer extension as shown in Fig. 3. Additional signals of mRNAs with a smaller size were observed probably resulting from partially degraded mRNA. The guanine residue 365 was identified as the $5^{\prime}$ terminus of the $\mathrm{mRNA}$ and corresponding -10 and -35 regions were detected upstream of guanine residue 365. A putative ribosome

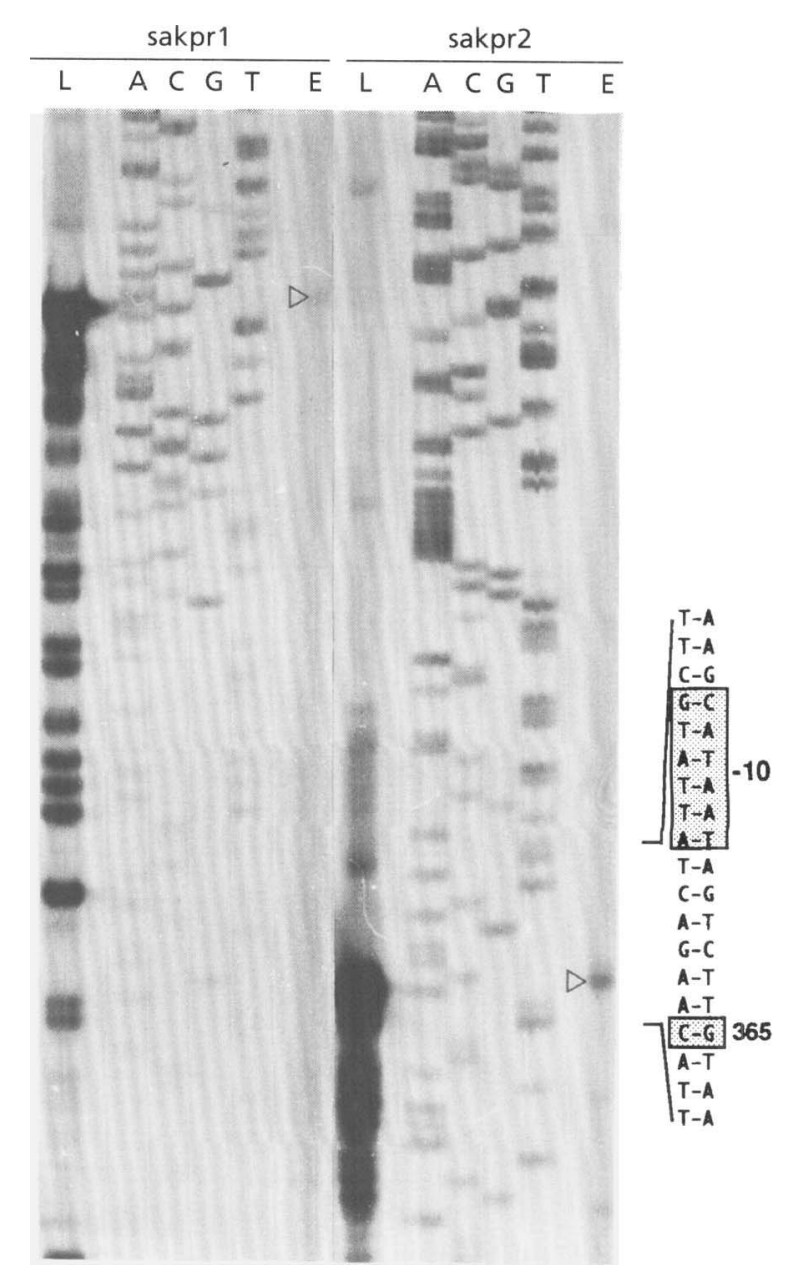

Fig. 3. Determination of the transcription initiation site in sakP. The result is depicted by sequence gel runs and a corresponding primer extension experiment with reverse transcriptase using two different oligonucleotides (sakpr 1 and sakpr2) directed against sakP mRNA. The sequence runs are marked $A, C, G$ and $\mathrm{T}$ for the dideoxy nucleotides used in the Sanger reaction. The primer extension lanes with mRNA from L. sake LTH 673 and $E$. coli NM554(pPT1000) are marked $L$ and $E$, respectively. Both signals marked by arrowheads indicate that guanine 365 is the starting point of transcription. The probable -10 region is boxed.

binding site was present $10 \mathrm{bp}$ upstream of the ATG specifying the $\mathrm{N}$-terminal methionine of pre-sakacin $\mathrm{P}$ (Fig. 2). In Northern hybridizations with RNA isolated from L. sake LTH 673, two signals were obtained corresponding to the mRNAs of 0.35 and $1.0 \mathrm{~kb}$ in length, respectively (results not shown). With RNA isolated from E. coli NM554 harbouring pPT1000 the same primer extension signal was obtained which was much less intense with the same amount of RNA applied (Fig. 3). This indicates weak transcription of sakP in the $E$. coli transformant. E. coli NM554 containing pPT1000 was not able to inhibit the indicator organism.

\section{Similarity to other bacteriocins}

Comparison with a DNA sequence databank (HUSAR) revealed similarity to pediocin PA-1 (Marugg et al., 1992) 


\begin{tabular}{|c|c|}
\hline $\begin{array}{l}\text { Curvacin A (1)/ } \\
\text { sakacin A (2) }\end{array}$ & 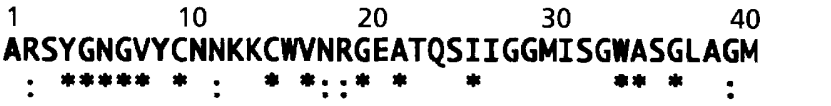 \\
\hline Sakacin P (3) & 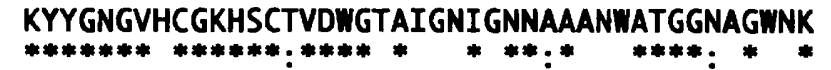 \\
\hline Pediocin PA-1 (4) & $\begin{array}{l}\text { jKATTCIINNGAMANATGGHQGNHKC } \\
: * * * *:\end{array}$ \\
\hline $\begin{array}{l}\text { Mesentericin Y } 105 \\
\text { (5) }\end{array}$ & $\underset{*}{\text { A- - - ASAGI }}$ \\
\hline Leucocin A (6) & EA----FSAGVHRLANGGNGFW \\
\hline
\end{tabular}

Fig. 4. Similarity of the mature sakacin $P$ to other bacteriocins. The presence of identical and related amino acids is indicated by * and :; respectively. (1), Tichaczek et al. (1993); (2), Holck et al. (1992); (3), this work: (4), Marugg et al. (1992); (5), Héchard et al. (1992); (6), Hastings et al. (1991).

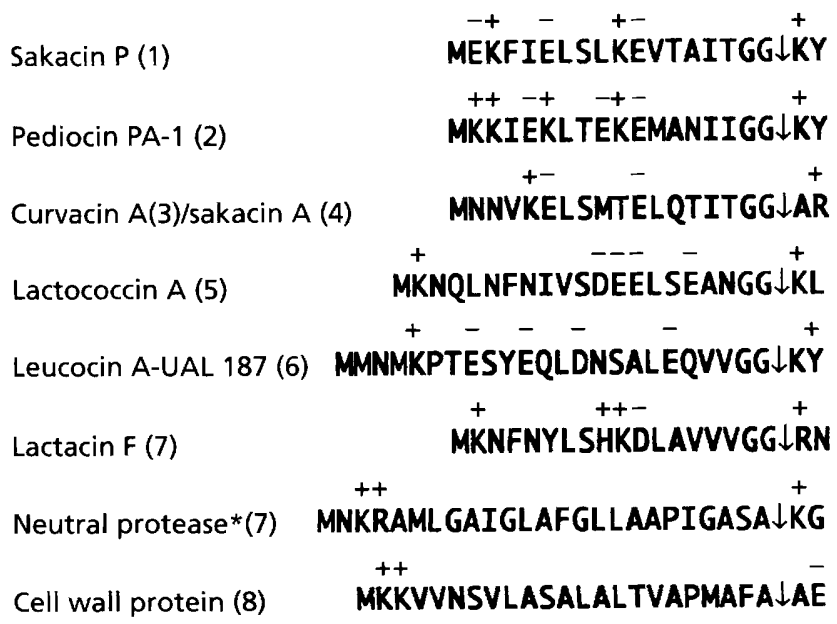

Fig. 5. Comparison of the leader sequences of small unmodified peptide bacteriocins. The cleavage site between pre-sequence and mature bacteriocin is indicated by an arrow. Two typical signal sequences from Bacillus species are added to demonstrate their dissimilarity to the bacteriocin leader sequences. Positively and negatively charged amino acids are indicated by + and - , respectively. The bacteriocin leader sequences share a GG consensus sequence at the cleavage site and absence of a hydrophobic core present in the signal peptides. (1), This work; (2), Marugg et al. (1992); (3) Tichaczek et al. (1993); (4), Holck et al. (1992); (5), Holo et al. (1991); (6), Hastings et al. (1991); (7), Muriana \& Klaenhammer (1991); (8), Simonen \& Palva (1993). The neutral protease $\left(^{*}\right)$ cleavage site was suggested, not experimentally proved.

and leucocin A-L'AL 187 (Hastings et al., 1991). As depicted in Fig. 4, further similarities to curvacin A ('Tichaczek et al., 1992, 1993) and mesentericin Y 105 (Héchard et al., 1992) were detected. The comparison of the amino acid sequences of the mature peptides is depicted in Fig. 4, the amino acid sequences of $\mathrm{N}$-terminal leader sequences common for peptide bacteriocins are shown in Fig. 5. No sequence homology to other proteins was found for the putative orf $X$ and orf $Y$ products.

\section{DISCUSSION}

The comparison of the amino acid sequence deduced from sakP with the amino acid sequence of sakacin $\mathrm{P}$ determined by Edman degradation of the purified bacteriocin, revealed that sakacin $P$ is synthesized as a prepeptide. The location of the putative AGGAG ribosome binding site $10 \mathrm{bp}$ upstream of the ATG at position 429 indicates that the methionine specified by this codon probably is the N-terminal end of pre-sakacin P (Thomas et al., 1982). Thus, sakP encodes a 61 amino acid prepeptide. The Nterminal leader peptide appears to be proteolytically cleaved off before or at secretion, because the biologically active substance does not contain this region. This leader sequence does not share any homology with conserved regions common in signal peptides (Simonen \& Palva, 1993). It lacks the typical hydrophobic $\alpha$-helix core region as it contains some charged amino acids which are also found in the leader sequences of other bacteriocins (Marugg et al., 1992). Furthermore, the presence of two glycine residues adjacent to the cleavage site in the $\mathrm{C}$ terminus of the leader sequence is common in prepeptides of unmodified small bacteriocins (Marugg et al., 1992). This type of cleavage site is not observed in typical signal peptides for exported proteins (Simonen \& Palva, 1993; Pugsley, 1993). The $\mathrm{C}$ terminus of the leader sequence with the Gly-Gly residues is inconsistent with the $(-3$, -1) rule of von Heijne (1988). A novel excretion mechanism for the bacteriocins, as has been described for lactococcins (Stoddard et al., 1992), may account for these differences from the expected structure of signal peptides (Gierasch, 1989). In contrast, the leader sequence might function as a chaperone maintaining a specific, inactive conformation of the bacteriocin (Tichaczek et al., 1993). Upstream of $s a k P$ a second ORF, orf $X$, is located which could encode a protein of 52 amino acids. The function of this putative protein remains unknown and it shares no sequence homology with any known protein. Sequence analysis of this region revealed the presence of a putative ribosome binding site $11 \mathrm{bp}$ upstream of the putative initiating methionine codon. Downstream of $\operatorname{orf} X$, a terminator sequence was detected suggesting that $\operatorname{orf} X$ forms a mRNA independent of sakP transcription.

Downstream of sakP another ORF, orf $Y$, was identified which could encode a protein of 98 amino acids. orf $Y$ is probably transcribed together with sakP from the same transcription initiation site. Transcription of sakP together with $\operatorname{orf} X$ upstream of sak $P$ is unlikely, due to a strong terminator structure between orf $X$ and $s a k P$. An operon consisting of a bacteriocin structural gene closely followed by an ORF of 90-110 amino acid residues seems to be a general feature for this type of bacteriocin (Hastings et al., 1991). These ORFs could encode immunity proteins (Hastings et al., 1991; Holo et al., 1991). The presence of immunity genes was demonstrated by van Belkum et al. (1992). These (putative) immunity proteins do not share amino acid sequence homology. 
Nevertheless, the length of orf $Y$ and its organization in one operon with sakP suggest a function of its product as an immunity protein. sakP was also transcribed as a single transcript. This may be due to a weak terminator structure between sakP and orf $Y$ in addition to the terminator downstream of orf $Y$. Studies on the expression of sak.P and immunity against sakacin $\mathrm{P}$ may reveal and confirm the role $\operatorname{orf} Y$.

\section{ACKNOWLEDGEMENTS}

This work was supported by the Bundesministerium für Forschung und Technologie grant $0319280 \mathrm{~B}$ and the Commission of the European Communities in the BRIDGE Tproject on Lactic Acid Bacteria Contract BIOT CT91 0263 (SSMA).

\section{REFERENCES}

Barefoot, S. F. \& Klaenhammer, T. R. (1983). Detection and activity of lactacin B, a bacteriocin produced by Lactobacillus acidopbilus. Appl Environ Microbiol 45, 1808-1815.

van Belkum, M. J., Hayema, B. J., Geis, A., Kok, J. \& Venema, G. (1989). Cloning of two bacteriocin genes from a lactococcal bacteriocin plasmid. Appl Environ Microbiol 55, 1187-1191.

van Belkum, M. J., Hayema, B. J., Jeeniga, R. F., Kok, J. \& Venema, G. (1991). Organization and nucleotide sequences of two lactococcal bacteriocin operons. Appl Environ Microbiol 57, 492-498.

van Belkum, M. J., Kok, J. \& Venema, G. (1992). Cloning, sequencing, and expression in Eschericbia coli of $\ln B$, a third bacteriocin determinant from the lactococcal bacteriocin plasmid p9B4-6. Appl Environ Microbiol 58, 572-577.

Buchman, G. W., Banerjee, S. \& Hansen, J. N. (1988). Structure, expression, and evolution of a gene encoding the precursor of nisin, a small protein antibiotic. $J$ Biol Chem 263, 16260-16266.

Daeschel, M. A. (1989). Antimicrobial substances from lactic acid bacteria for use as food preservatives. Food Technol 43, 164-167.

Daeschel, M. A. \& Klaenhammer, T. R. (1985). Association of a 13.6 megadalton plasmid in Pediococcus pentosaceus with bacteriocin activity. Appl Environ Microbiol 50, 1538-1541.

Dretzen, G., Bellard, M., Sassone-Corsi, P. \& Chambon, P. (1981). Recovery of DNA fragments from agarose gels using DEAEpaper. Anal Biocbem 112, 295.

Foegeding, P. M., Thomas, A. B., Pilkington, D. H. \& Klaenhammer, T. R. (1992). Enhanced control of Listeria monocytogenes by in situ-produced pediocin during dry fermented sausage production. Appl Environ Microbiol 58, 884890.

Gierasch, L. M. (1989). Signal sequences. Biochemistry 28, 923-930. Grinstead, D. A. \& Barefoot, S. F. (1992). Jenseniin G, a heat-stable bacteriocin produced by Propionibacterium jensenii P126. Appl Environ Microbiol 58, 215-220.

Hammes, W. P., Bantleon, A. \& Min, S. (1990). Lactic acid bacteria in meat fermentation. FEMS Microbiol Rev 87, 165-174.

Hanahan, D. (1983). Studies on transformation of Escherichia coli with plasmids. J Mol Biol 166, 557-580.

Hastings, J. W., Sailer, M., Johnson, K., Roy, K. L., Vederas, J. C. \& Stiles, M. (1991). Characterization of leucocin A-UAL 187 and cloning of the bacteriocin gene from Leuconostoc gelidum. J Bacteriol 173, 7491-7500.

Héchard, Y., Dérijard, B., Letellier, F. \& Cenatiempo, Y. (1992). Characterization and purification of mesentericin Y105, an anti-
Listeria bacteriocin from Leuconostoc mesenteroides. J Gen Microbiol 138, 2725-2731.

von Heijne, G. (1988). Transcending the impenetrable: how proteins come to terms with membranes. Biochim Biophys Acta 947 , 307-333.

Holck, A., Axelsson, S., Birkeland, S. E., Aukrust, T. \& Blom, H. (1992). Purification and amino acid sequence of sakacin $A$, a bacteriocin from Lactobacillus sake Lb 706. J Gen Microbiol 138, 2715-2720.

Holo, H., Nilssen, O. \& Nes, I. F. (1991). Lactococcin A, a new bacteriocin from Lactococcus lactis subsp. cremoris: isolation and characterisation of the protein and its gene. J Bacteriol 173, 3879-3887.

Jiménez-Dlaz, R., Rios-Sánchez, R. M., Desmazeaud, M., RuizBarba, J. L. \& Piard, J.-C. (1993). Plantaricin S and T, two new bacteriocins produced by Lactobacillus plantarum LPCO10 isolated from a green olive fermentation. Appl Environ Microbiol 59, 1416-1424.

Joerger, M. C. \& Klaenhammer, T. R. (1986). Characterization and purification of helveticin $\mathrm{J}$ and evidence for a chromosomally determined bacteriocin produced by Lactobacillus belveticus 481 . J Bacteriol 167, 439-446.

Joerger, M. C. \& Klaenhammer, T. R. (1990). Cloning, expression, and nucleotide sequence of the Lactobacillus belveticus 481 gene encoding the bacteriocin helveticin J. J Bacteriol 172, 6339-6347.

Klaenhammer, T. R. (1988). Bacteriocins of lactic acid bacteria. Biochimie 70, 337-349.

Lozano, J. C. N., Nissen-Meyer, J., Sletten, K., Pélaz, C. \& Nes, I. F. (1992). Purification and amino acid sequence of a bacteriocin produced by Pediococcus acidilactici. J Gen Microbiol 138, 1985-1990.

de Man, J. C., Rogosa, M., Sharpe, M. E. (1960). A method for the cultivation of lactobacilli. J Appl Bacteriol 23, 130-135.

Marugg, J. D., Gonzalez, C. F., Kunka, B. S., Ledeboer, A. M., Pucci, M. J., Toonen, M. Y., Walker, S. A., Zoetmulder, M. J. \& Vandenbergh, P. A. (1992). Cloning, expression, and nucleotide sequence of genes involved in production of pediocin PA-1, a bacteriocin produced from Pediococcus acidilactici PAC1.0. Appl Environ Microbiol 58, 2360-2367.

Mørtvedt, C. I. \& Nes, I. F. (1990). Plasmid-associated bacteriocin production by a Lactobacillus sake L45. J Gen Microbiol 136, 1601-1607.

Muriana, P. M. \& Klaenhammer, T. R. (1991). Cloning, phenotypic expression, and DNA sequence of the gene for lactacin $\mathrm{F}$, an antimicrobial peptide produced by Lactobacillus spp. J Bacteriol 173, 1779-1788

Obst, M. (1993). Genetische und physiologische Untersuchungen des Laktosemetabolismus von Lactobacillus sake und L. curvatus. $\mathrm{PhD}$ thesis, Universität Hohenheim, Germany.

Pugsley, A. (1993). The complete general secretory pathway in Gram-negative bacteria. Microbiol Rev 57, 50-108.

Sambrook, J., Fritsch, E. F. \& Maniatis, T. (1989). Molecular Cloning: a Laboratory Manual. Cold Spring Harbor, NY: Cold Spring Harbor Laboratory.

Schillinger, U., Kaya, M. \& Lücke, F. K. (1991). Behaviour of Listeria monocytogenes in meat and its control by a bacteriocin producing strain of Lactobacillus sake. J Appl Bacteriol 70, 473 478.

Simonen, M. \& Palva, I. (1993). Protein secretion in Bacillus species. Microbiol Rev 57, 109-137.

Stoddard, G. W., Petzel, J. P., van Belkum, M. J., Kok, J. \& McKay, L. L. (1992). Molecular analyses of the lactococcin A gene cluster 
from Lactococcus lactis subsp. lactis biovar diacetylactis WM4. Appl Environ Microbiol 58, 1952-1961.

Tagg, J. R., Dajani, A. S. \& Wannamaker, L. W. (1976). Bacteriocins of Gram-positive bacteria. Bacteriol Rev 40, 722-756.

Tichaczek, P. S., Nissen-Meyer, J., Nes, I. F., Vogel, R. F. \& Hammes, W. P. (1992). Characterization of the bacteriocins curvacin A from Lactobacillus curvatus LTH 1174 and sakacin P from $L$. sake L'TH673. Syst Appl Microbiol 15, 460 468.

Tichaczek, P. S., Vogel, R. F. \& Hammes, W. P. (1993). Cloning and sequencing of $c u r A$ encoding curvacin A, the bacteriocin produced by Lactobacillus curvatus LTH 1174. Arch Microbiol 160, 279 283.

Thomas, D. Y., Dubus, G. \& Narang, S. (1982). Escherichia coli plasmid vectors containing synthetic translational initiation sequences and ribosome binding sites fused with the lac $Z$ gene. Gene 19, 211-219.

Vincent, J. G., Veomett, R. C. \& Riley, R. F. (1959). Antibacterial activity associated with Lactobacillus acidophilus. J Bacteriol $\mathbf{7 8}$, 477-484.

Vogel, R. F., Pohle, B. S., Tichaczek, P. S. \& Hammes, W. P. (1993). The competitive advantage of Lactobacillus curvatus LTH 1174 in sausage fermentations is caused by formation of curvacin A. Syst Appl Microbiol 16, 457-462.

Wheater, D. M., Hirsch, A. \& Mattick, A.T. R. (1951). 'Lactobacillin', an antibiotic from lactobacilli. Nature 168, 659.

Received 7 June 1993; revised 3 September 1993; accepted 14 September 1993. 